\title{
KNOWLEDGE SHARING ACTIVITIES \\ IN THE ORGANIZATION OF REGIONAL SUPREME PRODUCT MANAGER
}

\author{
Bayu Indra Setia \\ bayuku_is@yahoo.com \\ Yana $\bar{R}$ ochdiana $\mathbf{H}$. \\ Annisa Adha M. \\ Faculty of Economics and Business, University of Pasundan \\ Jl. Tamansari No. 6-8 Bandung 40116
}

received: 29/03/18; revised: 25/05/18; published: 27/06/18

\begin{abstract}
The purpose of this study is to obtain empirical evidence of knowledge sharing activities in the organization of regional supreme product manager, as well as looking for factors that influenced it. The research method used was qualitative descriptive at sub-districts in Bandung, with sample of agencies, entrepreneurs, and related institutions. The ability to transform knowledge from supreme product managers and agencies to managers of products that had not become a supreme was yet optimal. It is because of the area that was not possible and its supreme product managers who did not want to share their knowledge to another products managers that had not become supreme because they fear of being competed. Nevertheless, government agencies had always understood the need for other knowledge to facilitate routine improvements of product managers that had not become supreme, such as supreme product standardization training, and requirements that must be met to become supreme product.
\end{abstract}

Keywords: supreme product; knowledge sharing

\section{INTRODUCTION}

Potential is something that can be used as material or source that will be managed either through human effort or done through the power of machine where the process of potency can also be interpreted as a resource that is around us. Regional supreme potential is a mainstay product in an area that has the most advantageous value to be cultivated or developed in a region (Depkimpraswil , 2003). Regional Supreme Product, hereinafter abbreviated as RSP, is a product, either in the form of goods or services, produced by cooperatives, small and medium scale businesses that are potential to be developed by utilizing all resources owned by the area of good natural resources, human resources and local culture, and bringing income for the community and government which is expected to become an economic power for the region and the local community as a potential product that has the competitiveness, selling power, and driving force and ability to enter the global market (Permendagri No. 9 of 2014).

Based on data from the Department of Industry, Trade, Cooperatives and SMEs Bandung in 2015 set thirty industrial centers scattered in Bandung. These thirty centers are the central points of the development of SMEbased industries that have developed in Bandung with various products, such as textile, food, dolls, and others. The pattern of SME distribution is still concentrated in some areas, not spread in the 30 districts in Bandung. This is caused by sporadic spreading pattern of SMEs and limited infrastructure facilities. Therefore, SMEs prefer to be in the location that is reachable by consumers.

The problem of various knowledge in an organization today becomes an important issue both in business and non-business, because all human activity are actually organizing activity. No activity will run smoothly, if there is no good organization. No benefits or profit can be gained, if the organization is not going well. Every organization has members who work based on their knowledge. Managing their ultimate knowledge means managing the members as well as managing people.

The importance of knowledge sharing is put forward by Srivastava (in Martini and Tjakraatmadja, 2011) who stated that if existing knowledge of the organization is not shared, the available cognitive resources to the organization will be useless. Through knowledge sharing, knowledge in the organization will increase and form new knowledge, improve personal and organizational quality. As with other types of 
organizations, the development and growth of SMEs in each sub-district depends on the process of knowledge sharing to be able to continue to absorb, provide, and create new knowledge for sub-districts that do not yet possess and meet the criteria of excellent products. This is reinforced by the opinion of Noris (2003) which stated that knowledge sharing is an obligatory activity in government agencies given to businessmen and should always be developed to maintain sustainability and achieve competitive advantage.

Problems occur when there is knowledge sharing activities undertaken by the government, both in provincial and local governments to local agencies associated with supreme products. If all become supreme products, it will increase investment for the area.

The following phenomena about supreme products of MSMEs of Bandung Regency stated that the products are still less competitive, because of various constraints and one of them lacks of knowledge transfer or knowledge sharing. The number of micro, small and medium enterprises (MSMEs) in Bandung Regency are claimed to continue to grow. The percentage increase, compared to the previous year, in the number of MSME's owners that reached $102.7 \%$ from 7,894 units to 16,002 owners of MSMEs. In its development, MSME growth in Bandung Regency also faced various challenges. One of them is the development of promotion and marketing of supreme products produced by MSME.

Disclosed by the Regional Chairman of the National Craft Board of Bandung Regency, Nia Kurnia Dadang Naser, the development of promotion and marketing of supreme products must be systematically done by involving various components. This is deemed necessary in the midst of MSMEs that still have limitations, both in terms of capital and human resources.

Regional Supreme Product (RSP) is a good or service owned and controlled by a region, which has economic value and high competitiveness and absorbs a large amount of labor, produced based on technical feasibility considerations (raw materials and markets), community talent and institutional (technological mastery, human resource capability, infrastructure support, and socio-cultural conditions) that develop in certain locations. Local economic development is a process of building dialogue and partnership actions of stakeholders including local governments, entrepreneurs, and local community organizations. The main pillars of the strategy are to increase the attractiveness, endurance, and competitiveness of the local economy. The main objective is to create high growth and sustainable development that benefits all parties in the region in order to significantly improve new employment and reduce poverty (Nusantoro, 2011).

The supreme products produced by MSMEs spread in 31 sub-districts throughout Bandung Regency. These supreme products are potential owned by Bandung Regency to continue to be developed. However, some of the products are still not ready to be marketed due to some obstacles, said Niaatthe opening of design knowledge improvement training for 100 MSME's owners in Bandung regency, in the Dewi Sartika Building, Bandung Regency Government Office Complex, Tuesday (3/11/2015).

On the occasion, disclosed Nia, product design training is one of the breakthroughs made by Dekranasda of Bandung Regency to help MSME's owners. The goal is to help MSME's owners to be able to compete to other products in the market. The reason is to compete with the current condition in the free market. However, it's not enough for the products to compete with the only improvement of the quality itself, but it also must be supported by the skill of making designs in order to produce attractive products for potential buyers. To improve product marketing, Dekranasda of Bandung Regency always invites MSME's owners to participate in supreme product exhibitions, both in regional and national level.

The above phenomenon shows that the importance of knowledge sharing process among supreme products in a region is really crucial. This is because knowledge sharing will further help MSEs get a lot of knowledge about how to create a supreme product in a region that can be further developed and advanced. Based on the above background, the urgency of this research is that problems occur when there is knowledge sharing activities undertaken by the government, both in provincial and local governments to local agencies associated with supreme products. If all become supreme products, it will increase investment for the area.

Knowledge management is the overall management of the process of knowledge creation or development, the process of knowledge storage and knowledge sharing process and the process of knowledge implementation in order to exploit the tacit and explicit assets possessed by the organization in order to achieve competitive advantage (Nonaka, 2007; Rusilowati, 2017). According to Rusilowati (2017), knowledge management is a systematic process in finding, selecting, organizing, filtering and presenting information in a particular way that can enhance the mastery of knowledge in a specific field of study. In general, KM is a technique for managing knowledge in organizations to create value and enhance competitive advantage.

According to Jones (2009), knowledge management is inherently collaborative, thus a variety of collaboration technologies can be used to support knowledge management practices. Collaborative knowledge management tools that allow people to share documents, make comments, engage in discussion, create schematic diagrams, and so on can be valuable aids to support organizational learning. While according to Liao (2010) knowledge management capabilities (i.e., knowledge acquisition, knowledge conversion, and knowledge application) are rooted in the operation of a firm and are derived from configurations of organizational structure and culture. 
According to Antonova (2006), knowledge management is not about managing technology alone, but is about managing how human beings can share their knowledge effectively. The 'real' information system is built upon organizational culture and interpersonal communication and contains rich and dynamic tacit knowledge, which, if it is effectively harnessed and managed, it can also give organizations competitive advantage. Sharing expertise requires building culture of trust, and any organizational practice or action that destroys trust adversely affects the motivation to share information with others.

Knowledge is a mix of experience, values, contextual information and expert insights that provide a framework for evaluating and incorporating new experiences and information. Meanwhile, according to Alavi and Liedner (2001), knowledge is information that has been validated and confirmed which is used to take decisions and actions to be taken.

Sharing knowledge is a method of a group in sharing knowledge, techniques, experiences and ideas they have with other members. According to Subagyo (2007) knowledge sharing is one of the methods or one of the steps in knowledge management used to provide an opportunity for members of a group, organization, agency or company to share knowledge, techniques, experiences and ideas they have to other members. Knowledge sharing can only be done when each member has a wide opportunity to express his opinions, ideas, criticisms and comments to other members.

The use of the term sharing affirms the process of presenting individual knowledge into a form that is more easily understood by others. The term sharing also affirms that it does not mean the possessor of knowledge or a person possessing knowledge disposes of his ownership, but rather forms a common ownership between the sender and receiver of such knowledge (Rusilowati, 2015). Reporting involves the exchange of information based on a structured routine or format, whereas sharing involves self-awareness of individuals participating in the exchange of knowledge even though there is no necessity to do so. Another opinion from Hendriks (1999) in Rusilowati (2015) stated that knowledge sharing involves at least a relationship between two parties, namely those who master the knowledge and those who seek to master the knowledge.

M. Hosein Fallah and Sherwat Ibrahim (2004) stated that knowledge from an accessibility perspective shows that the accessibility mechanism in the technology group is different in terms of explicit knowledge. The process of socialization and the exchange of unmodified knowledge requires direct interaction to be transmitted, this occurs at the individual, corporate or national level. Unmodified knowledge is not the only source of unique knowledge for technological groupings, knowledge embedded in the cluster itself such as socio-culture and other semantics of knowledge is best obtained by placing it in the cluster itself.
Kemme, et.al. (2009) stated that there are number of government policies that must be done to increase the ability of the sector to attract investment by providing greater knowledge of the business so that the results directly result from the products produced. In addition, to increase the level of knowledge and technical expertise in understanding the economic situation in the future. In this study, there are also dividends, et al. find a copy of the maximum copy of companies and local companies. Our findings have several implications in many cases.

David, et.al. (2009) stated that there is a government policy that must be done to improve the ability of a sector to attract foreign investment by giving businesses greater knowledge directly. It produces added value from the products. In addition, to increase the level of knowledge and technical expertise in understanding the current economic situation. There was a horizontal spillover effect from the activities of foreign companies and local companies.

King (2009) stated that knowledge management focuses on knowledge processes - knowledge creation, acquisition, refinement, storage, transfer, sharing and utilization. These processes support organizations that involve innovation, individual learning, teaching learning and collaborative decision making. Outcomes of management knowledge are organizational behaviors, decisions, products, services, processes and relationships that enable the organization to improve the overall performance of products and the SME organization itself.

Argote and Ingram (2000) stated that by instilling knowledge in interactions involving people, the organization can influence the transfer of knowledge internally and inhibit external transfer of knowledge. With this, knowledge is embedded in the interaction of people, tools, and tasks giving the basis for superior competitiveness in the company.

Zyl and Echendu (2007) stated that in increasing the performance of organizations in the competition, the world needs transfer of knowledge of business people, academia and government agencies in three elements of collaborative collaboration as: (a) the need to extract appropriate knowledge at the right time to make important decisions; (b) knowledge is a valuable source; (c) emphasis on obtaining research investment; (d) the need to protect knowledge for superior competitiveness; (e) the need to cover knowledge gaps; (f) international trade; $(\mathrm{g})$ the need to protect intellectual property as a patent and trademark; (h) proximity to geographical sources of knowledge and recipients; and (i) war, terrorism and natural disasters.

The research has relationship with previous studies, namely studies related to supreme products both supreme product investment and development of potential supreme products. The research roadmap chart is as shown in Figure 2. 


\section{METHODS}

The research method used is descriptive with qualitative approach. This research was a descriptive research that described the actual situation of the object under study, according to the actual situation at the time of direct research. The principle of qualitative research was naturalistic or natural. It is called naturalistic because the research field situation was "natural" or reasonable, as it was, without being manipulated, organized by experiment or test. This study did not test a hypothesis, but only want to know the state of the variable loosely. It also did not connect between variable with another variable systematically. Therefore, qualitative approach is used in this research.

The design of the study was established as a research operational engineering to be well implemented in order to minimize the error element. Related to this matter, this research also formed a design that contains planning and execution of referred research. Below is series of activities that would be implemented for one year: (1) Activity Socialization Stage, (2) Preparation Stage Survey, (3) Introduction Study Stage, (4) Preliminary Survey \& Observation, (5) Data Processing \& Analysis of Survey and Observation Results, (6) Socialization of Data Analysis Results, (7) Article Writing, (8) Script Delivery of Scientific Articles to National Journal, (9) Making Textbooks, (10) Reporting Results of Activities.

This analysis required database of economic conditions, supreme and potential sectors, all areas in Bandung that were always updated both by the relevant agencies and by each sub-district. In the activity approach, the researcher considered that at the stages of its activities, the approach would be divided into several approaches namely: (1) Literature Study on pre-eminent and potential sector-related legislation and regulatory documents as an initial stepping-stone in the preparation of the next step in Activities of Knowledge Sharing in the Organization of Regional Supreme Product Manager. From this literature study, we would obtain basic information about the supreme and potential sectors so the established goals could be achieved, (2) Instance Surveys, surveys to agencies related to Activities of Knowledge Sharing in the Organization of Regional Supreme Product Manager in 30 Sub-districts of Bandung City. Activities undertaken, among others, data inventory to be collected into a data base containing information about supreme and potential sectors. As described earlier this institutional survey was an activity undertaken to obtain documents of regional development plans that already exist in each SKPD related. In relation to the implementation of the study, the institutional survey will also conduct primary data collection with depth-interview with several stakeholders in the preparation of Activities of Knowledge Sharing in the Organization of Regional Supreme Product Manager. As for the documents required for Activities of Knowledge Sharing in the Organization of Regional Supreme Product Manager in 30 Sub districts of Bandung, namely: (a) PDRB Data of Bandung, (b) Input and Output Data of Bandung, (c) Interregional Input-Output Data of Bandung, (d) Bandung Industrial Development Policy Document and OVOP (One Village One Product) product development document, (e) RTRW Document of Bandung, (f) Incentive and Disincentive Policy of Bandung, (3) Depth Interview. In Activities of Knowledge Sharing in the Organization of Regional Supreme Product Manager in 30 Sub-districts, Bandung held Depth interview with related stakeholders. This activity was done to capture the input and do the agreement with related stakeholders as the strategy preparation material with key person. Depth interview shall be made to the related agencies and business owners, in this case, the supreme product managers.

\section{RESULTS}

Based on the results of primary and secondary surveys that have been conducted in previous research, we obtained a number of similarities between the survey method of the sub district questionnaire and LQ-based analysis of regional economic analysis as the basis of the sub district supreme sector. The conclusions obtained from the survey are shown in Table 1.

\section{DISCUSSION}

Basically, supreme product managers and related institutions such as sub-districts, Bappeda, MSME agency, regularly invite experts (for example through seminars, training, workshops, etc.) to gain new knowledge to support the latest information that is the current trend. In addition to this, they also cooperate with the experts so that the product managers could collaborate and be able to get information about the wishes of users who use products or services of the product managers.

Furthermore, supreme product managers have the ability to assimilate the knowledge. In other words, the supreme product manager cannot basically yet promote the results of the product without the help of an agency, so the government agencies always involve them in every activity related to the exhibition of regional supreme products. With these activities the supreme product managers will get and add insight and knowledge on how to manage good products in order to attract the consumers.

The ability to transform the knowledge provided from the leading product managers and agencies to the non-supreme product managers is still not optimal because there is still a fundamental problem. There is also still a supreme product manager who do not want to share knovwledge to the non-supreme product managers because of the fear of being competed. Nevertheless, government agencies have always understood the need for other knowledge to facilitate routine improvements 
from non-supreme product managers such as standard product standardization training, requirements that must be met to become a supreme product, etc.

Government agencies and supreme product managers are constantly assisting non-supreme product managers to improve their skills by providing knowledge to have strong competitiveness, and they always hold discussions once every 3 months in a year, to overview the progress of the knowledge they got. If there were a slight of mistake, supreme product managers and agencies were able to retrace the steps and take actions that should have been done to understand what really happened. Therefore, there will be later an evaluation that encourages the increased competence of business owners through participation in internal and external training.

Thus, it can be concluded that a good system is still not supported with good human resource, because human resources are not ready, a good system cannot be used as much as possible so that there must be a synchronization between the system used with the competence of human resources needed.

In addition to the various factors that enable the implementation of knowledge sharing, there are also barriers that lead to knowledge sharing becoming difficult to apply to SMEs, they are: (a) The lack of tools in applying knowledge sharing to SMEs, (2) The assumption that knowledge sharing requires a large amount of capital, (3) The limited quality of human resources leads to a lack of mastery of knowledge making it difficult to accept new methods

One of the factors that make it difficult to share knowledge is the difficulty of finding tools that can be used to share, besides that not everyone can use it. Facilities and infrastructure in question here are standard tools that can be used by business or SMEs. The term Knowledge Sharing can be said to be something new for SMEs, therefore the lack of adequate tools cause SMEs to have difficulty to implement. Besides, it is also necessary knowledge and understanding in advance about knowledge sharing itself. A new method or knowledge is usually synonymous with cost, in other words, it requires a large enough cost to get the required knowledge. The cost is required for both training, seminars, short courses and formal education. Because of limited funds, knowledge becomes difficult to obtain for use or development within the company. In applying knowledge sharing, it does not cost a lot. Knowledge sharing is a method that can be done by all parts independently without the presence of a third party who always accompanies. However, it requires a start so that some or all staff are able to understand and implement knowledge sharing. Another obstacle is the limited quality of human resources in SMEs, leading to a lack of mastery of knowledge so that it is relatively difficult to accept a new method such as knowledge sharing. The number of SM Entrepreneurs who have a diploma from university is only about $2.20 \%$. This limitation directly causes problems not only in the implementation of knowledge sharing, but also when it is not implemented. Limited knowledge mastery causes SMEs to become obstructed in implementing technologies or methods that are generally implemented. Prior to its implementation of knowledge sharing, SMEs have been preoccupied in advance by internal problems that can hinder and disrupt the rate of business growth and development.

\section{CONCLUSIONS}

Facing the existence of such a tight competition, the implementation of Knowledge Sharing can be a solution for SMEs, including to increase productivity by improving the competitiveness of SMEs. Implementation of knowledge sharing in SMEs can be implemented through several stages, starting with information gathering, analysis, design then internalization and evaluation. Implementation of knowledge sharing on SMEs is done in a simple way, this is due to the presence of various limitations on SMEs.

The most important factors affecting knowledge sharing that can be implemented in SMEs are human and cultural factors. Humans, as character and the main subject of SMEs, should systematically be able to accept, realize, understand and implement knowledge sharing. Without the support of both, the implementation of knowledge sharing cannot properly work. In addition, there are various barriers that make it is difficult for knowledge sharing to be implemented in SMEs, for example, the absence of tools and the assumption that a knowledge requires a large cost and limited quality of human resources. It makes knowledge mastery become less.

\section{REFERENCES}

Alavi, Maryam and Dorothy E. Leidner. 2001. Knowledge Management and Knowledge Management Systems: Conceptual Foundation and Research Issues. MIS Quarterly 1 (10):107136. March.

Antonova, Albena; Gourova, Elissaveta. 2006. A Note on Organizational Learning and Knowledge Sharing in the Context of Communities of Practice. CIST, Sofia University, 125, Tzarigradsko Shausse Blvd. bl.2, Sofia 1113, Bulgaria. https://www.researchgate. net/.../32231445.

Argote, L, and Ingram, P. 2000. Knowledge transfer: a Basis for Competitive Advantage in Firms. Organizational Behaviour and Human Decision Processes, 82, 150-169, January.

Departemen Permukiman dan Prasarana Wilayah (Depkimpraswil). 2003.

Fallah, M. Hosein; Sherwat Ibrahim. 2004. Knowledge Spillover and Innovation in Technological Clusters. IAMOT. 
Jones, Kiku and Lori N. K. Leonard. 2009. From Tacit Knowledge to Organizational Knowledge for Succesfull KM. www.uky.edu.

Kemme, David M.; Volodymyr Lugovskyy, Deepraj Mukherjee. 2009. Labor Mobility, Knowledge Transfer and Productivity Spillover: Evidence from Indian Firms. JEL classification: F23, O1.

King, William R. 2009. Knowledge Management and Organizational Learning. Annals of Information Systems 4, DOI 10.1007/978-1-4419-0011-1_1, (C) Springer Science+Business Media, LLC.

Liao, Shu-Hsien. 2010. Knowledge Management and Innovation: The Mediating Effects of Organizational Learning. Conference Paper: Industrial Engineering and Engineering Management. January.

Martini, Lenny and Jann Hidayat Tjakraatmadja. 2011. Berbagi Pengetahuan Di Institusi Akademik, Journal Manajemen Teknologi, 10(2): 196 -211.

Nonaka, Ikujiro. 2007. The Knowledge-Creating Company. Harvard Business Review. July-August Isuue.
Nusantoro, Jawoto. 2011. Model Pengembangan Produk Unggulan Daerah Melalui Pendekatann Klaster Di Provinsi Lampung. Fakultas Ekonomi Universitas Muhammadiyah Metro. https://jurnal.unimus.ac.id.

Peraturan Menteri Dalam Negeri No. 9 Tahun 2014 tentang Pedoman Pengembangan Produk Unggulan Daerah.

Rusilowati, Umi. 2017. Analisis Manajemen Pengetahuan Berbasis Teknologi Informasi (Studi Kasus Pada Lemlitbang Pemerintah Pengambil Kebijakan), Jurnal Organisasi dan Manajemen 11 (1), $44-61$.

Subagyo, Hendro. 2007. Pengantar Knowledge Sharing untuk Community Development. Modul Pelatihan Knowledge Management.

Zyl, A. van; J. Amadi-Echendu; T.J.D. Bothma, 2007. Nine Drivers of Knowledge Transfer between Universities and Industry R\&D partners in South Africa, South African Journal of Information Management. Vol 9 No.1.

\section{APPENDIX}

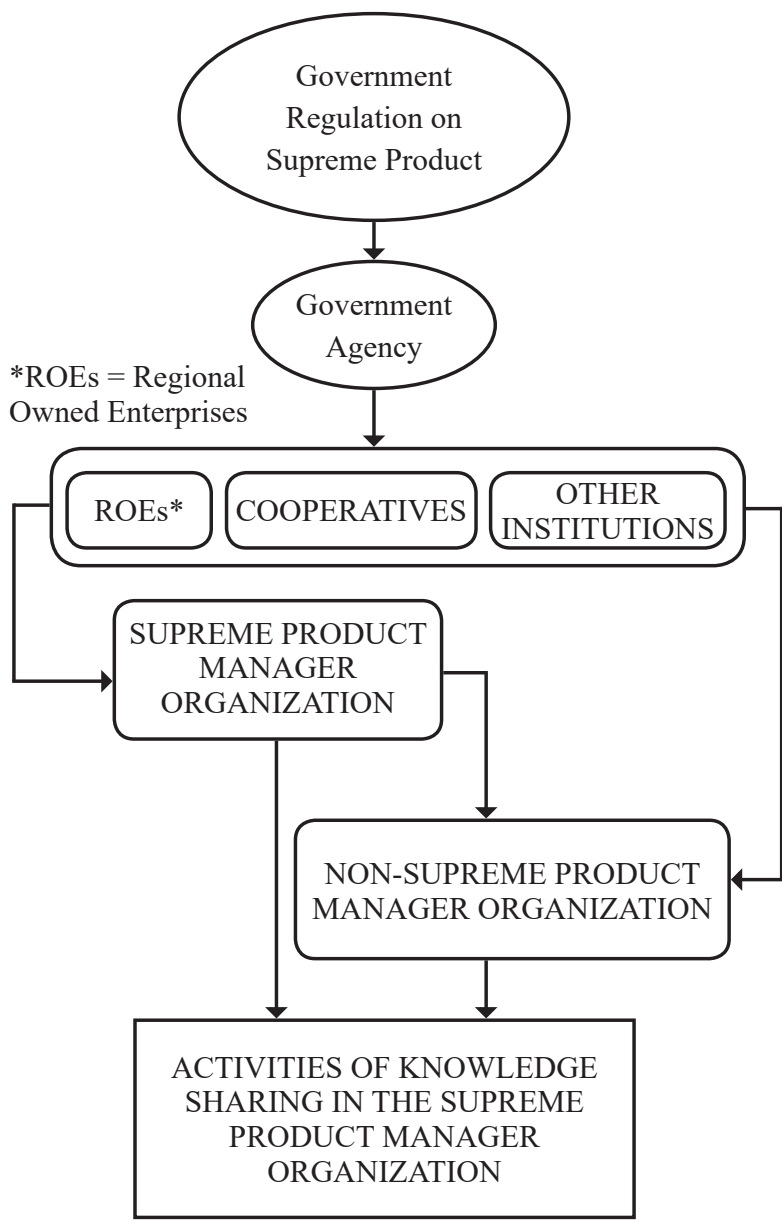

Figure 1. Research Framework
Table 1. Potential \& Commodity of Sub-districts

\begin{tabular}{|c|c|c|c|}
\hline \multirow{2}{*}{ No } & \multirow{2}{*}{ Subdistrict } & \multicolumn{2}{|c|}{ Survey Results } \\
\hline & & Potential & Commodity \\
\hline 1 & $\begin{array}{l}\text { Bandung } \\
\text { Kulon }\end{array}$ & $\begin{array}{l}\text { Processing } \\
\text { Industry }\end{array}$ & $\begin{array}{l}\text { Food and Beverage } \\
\text { Convection and Clothing } \\
\text { Accessories and Craft }\end{array}$ \\
\hline 2 & $\begin{array}{l}\text { Babakan } \\
\text { Ciparay }\end{array}$ & $\begin{array}{l}\text { Trade, Hotel, } \\
\text { Restaurant } \\
\text { (THR) } \\
\text { Processing } \\
\text { Industry }\end{array}$ & $\begin{array}{l}\text { Large Trading } \\
\text { Clothing Convection } \\
\text { Food and Beverage }\end{array}$ \\
\hline 3 & $\begin{array}{l}\text { Bojongloa } \\
\text { Kaler }\end{array}$ & $\begin{array}{l}\text { Processing } \\
\text { Industry }\end{array}$ & $\begin{array}{l}\text { Leather, Bag, Shirt and } \\
\text { Shoes } \\
\text { Food and Beverage } \\
\text { Craft }\end{array}$ \\
\hline 4 & $\begin{array}{l}\text { Bojongloa } \\
\text { Kidul }\end{array}$ & $\begin{array}{l}\text { Processing } \\
\text { Industry }\end{array}$ & $\begin{array}{l}\text { Leather, Bag, and Shoes } \\
\text { Food and Beverage }\end{array}$ \\
\hline 5 & Astana Anyar & $\begin{array}{l}\text { Services } \\
\text { Processing } \\
\text { Industry }\end{array}$ & $\begin{array}{l}\text { Tourism, Trading } \\
\text { Food and Beverage } \\
\text { Craft, Leather, Bag, and } \\
\text { Shoes }\end{array}$ \\
\hline 6 & Regol & $\begin{array}{l}\text { THR } \\
\text { Services } \\
\text { Processing } \\
\text { Industry }\end{array}$ & $\begin{array}{l}\text { Trading, Hotel } \\
\text { Service Company } \\
\text { Food and Beverage }\end{array}$ \\
\hline 7 & Lengkong & $\begin{array}{l}\text { Processing } \\
\text { Industry } \\
\text { THR }\end{array}$ & $\begin{array}{l}\text { Steel andSpare part, } \\
\text { Craft, Shirt, Handicraft } \\
\text { Trading }\end{array}$ \\
\hline 8 & $\begin{array}{l}\text { Bandung } \\
\text { Kidul }\end{array}$ & $\begin{array}{l}\text { Processing } \\
\text { Industry } \\
\text { THR }\end{array}$ & $\begin{array}{l}\text { Accessories and Craft } \\
\text { Food and Beverage } \\
\text { Apartment }\end{array}$ \\
\hline
\end{tabular}




\begin{tabular}{|c|c|c|c|c|c|c|c|}
\hline 9 & Gedebage & $\begin{array}{l}\text { THR } \\
\text { Processing } \\
\text { Industry }\end{array}$ & $\begin{array}{l}\text { Trading } \\
\text { Building and Furniture } \\
\text { Convection and Clothing }\end{array}$ & 20 & BuahBatu & $\begin{array}{l}\text { Processing } \\
\text { Industry } \\
\text { THR }\end{array}$ & $\begin{array}{l}\text { Accessories and Craft } \\
\text { Food and Beverage } \\
\text { Housing, Office, Hotel }\end{array}$ \\
\hline 10 & Cibiru & $\begin{array}{l}\text { Processing } \\
\text { Industry } \\
\text { Services } \\
\text { Farm }\end{array}$ & $\begin{array}{l}\text { Accessories and Craft } \\
\text { Entertainment and } \\
\text { Recreation Service } \\
\text { Cow Chop }\end{array}$ & 21 & $\begin{array}{l}\text { Sumur } \\
\text { Bandung }\end{array}$ & $\begin{array}{l}\text { Services } \\
\text { Processing } \\
\text { Industry }\end{array}$ & $\begin{array}{l}\text { Entertainmentand } \\
\text { Recreation Service } \\
\text { Accessories and Craft } \\
\text { Convection and Clothing }\end{array}$ \\
\hline 11 & Panyileukan & $\begin{array}{l}\text { Processing } \\
\text { Industry } \\
\text { THR }\end{array}$ & $\begin{array}{l}\text { Convection and Clothing } \\
\text { Trading } \\
\text { Food and Beverage }\end{array}$ & 22 & Andir & $\begin{array}{l}\text { Processing } \\
\text { Industry } \\
\text { THR }\end{array}$ & $\begin{array}{l}\text { Accessories and Craft } \\
\text { Large Trading } \\
\text { Food and Beverage }\end{array}$ \\
\hline 12 & $\begin{array}{l}\text { Ujung } \\
\text { Berung }\end{array}$ & $\begin{array}{l}\text { Processing } \\
\text { Industry } \\
\text { Services }\end{array}$ & $\begin{array}{l}\text { Food and Beverage } \\
\text { Convection and Clothing } \\
\text { Tourism }\end{array}$ & 23 & Cicendo & $\begin{array}{l}\text { Processing } \\
\text { Industry }\end{array}$ & $\begin{array}{l}\text { Convection and Clothing } \\
\text { Accessories and Craft } \\
\text { Steel and Spare part }\end{array}$ \\
\hline 13 & Cinambo & $\begin{array}{l}\text { Processing } \\
\text { Industry }\end{array}$ & Food and Beverage & 24 & $\begin{array}{l}\text { Bandung } \\
\text { Wetan }\end{array}$ & $\begin{array}{l}\text { Processing } \\
\text { Industry }\end{array}$ & Convection and Clothing \\
\hline 14 & Arcamanik & $\begin{array}{l}\text { Processing } \\
\text { Industry } \\
\text { THR }\end{array}$ & $\begin{array}{l}\text { Food and Beverage } \\
\text { Accessories and Craft, } \\
\text { Convection and Clothing } \\
\text { Housing, Office }\end{array}$ & 25 & $\begin{array}{l}\text { Cibeunying } \\
\text { Kidul } \\
\text { Cibeunying }\end{array}$ & $\begin{array}{l}\text { Processing } \\
\text { Industry } \\
\text { Printing } \\
\text { Processing }\end{array}$ & $\begin{array}{l}\text { Convection and Clothing } \\
\text { Accessories and Craft } \\
\text { Screen Printing } \\
\text { Food and Beverage }\end{array}$ \\
\hline 15 & Antapani & $\begin{array}{l}\text { Processing } \\
\text { Industry }\end{array}$ & $\begin{array}{l}\text { Steel and Spare part } \\
\text { Accessories and Craft } \\
\text { Food and Beverage }\end{array}$ & & Kaler & $\begin{array}{l}\text { Industry } \\
\text { Services }\end{array}$ & $\begin{array}{l}\text { Convection and Clothing } \\
\text { Entertainment and } \\
\text { Recreation Service }\end{array}$ \\
\hline 16 & Batununggal & $\begin{array}{l}\text { Processing } \\
\text { Industry }\end{array}$ & $\begin{array}{l}\text { Accessories and Craft } \\
\text { Food and Beverage } \\
\text { Leather, Bag, and Shoes }\end{array}$ & 27 & Coblong & $\begin{array}{l}\text { Processing } \\
\text { Industry } \\
\text { THR }\end{array}$ & $\begin{array}{l}\text { Food and Beverage } \\
\text { Convection and Clothing } \\
\text { Hotel }\end{array}$ \\
\hline 17 & Kiaracondong & $\begin{array}{l}\text { Processing } \\
\text { Industry }\end{array}$ & $\begin{array}{l}\text { Convection and Clothing } \\
\text { Food and Beverage } \\
\text { Accessories and Craft }\end{array}$ & 28 & Sukajadi & $\begin{array}{l}\text { Processing } \\
\text { Industry } \\
\text { THR }\end{array}$ & $\begin{array}{l}\text { Accessories and Craft } \\
\text { Large Trading }\end{array}$ \\
\hline 18 & Mandalajati & $\begin{array}{l}\text { Processing } \\
\text { Industry }\end{array}$ & $\begin{array}{l}\text { Food and Beverage } \\
\text { Accessories and Craft } \\
\text { Convection and }\end{array}$ & 29 & Sukasari & $\begin{array}{l}\text { Processing } \\
\text { Industry }\end{array}$ & $\begin{array}{l}\text { Accessories and Craft } \\
\text { Food and Beverage } \\
\text { Convection and Clothing }\end{array}$ \\
\hline 19 & Rancasari & $\begin{array}{l}\text { Processing } \\
\text { Industry }\end{array}$ & $\begin{array}{l}\text { Clothing } \\
\text { Food and Beverage } \\
\text { Accessories and Craft }\end{array}$ & 30 & Cidadap & $\begin{array}{l}\text { THR } \\
\text { Processing } \\
\text { Industry }\end{array}$ & $\begin{array}{l}\text { Hotel } \\
\text { Food and Beverage }\end{array}$ \\
\hline
\end{tabular}

Source : Data processing result

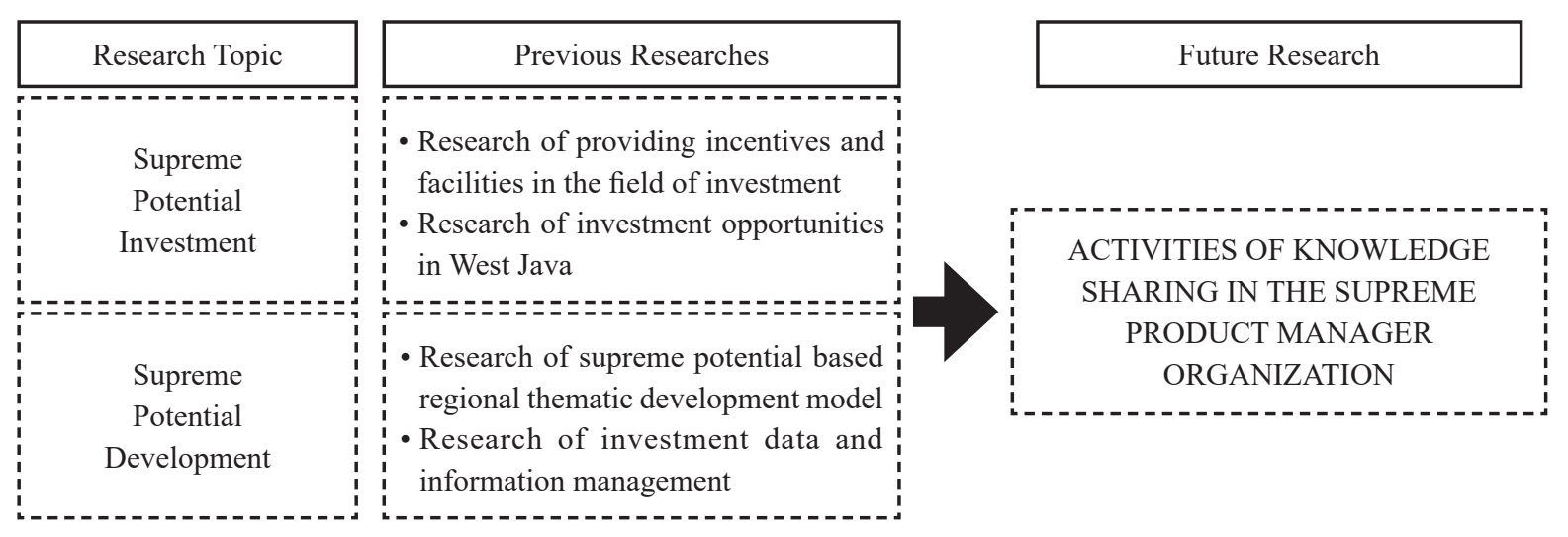

Figure 2. Research Roadmap 